\title{
Teacher Experiences in Converting Classes to Distance Learning in the COVID-19 Pandemic
}

\author{
Michael W. Marek, Wayne State College, USA \\ (iD) https://orcid.org/0000-0003-3784-1287 \\ Chiou Sheng Chew, Universiti Teknologi MARA, Shah Alam, Malaysia \\ (iD) https://orcid.org/0000-0002-6718-4663
}

Wen-Chi Vivian Wu, Asia University, Taichung City, Taiwan

\begin{abstract}
The authors conducted a worldwide survey to explore the experiences of higher education faculty who converted classes to distance learning during the COVID-19 pandemic. Most respondents experienced much higher workloads and stress than in face-to-face classes. Previous experience with Online Distance Learning (ODL) predicted positive faculty response. Less than half used a schoolprovided LMS, instead using a wide range of other technologies. Respondents said they learned the need for adaptability and good planning, emphasizing doing what it takes to serve their students. There was high variability in most answers, indicating that the experiences of individual teachers ranged widely between positive and negative. The researchers provide recommendations based on the findings, including the need for better ODL instructional design training as part of long-term professional development for faculty and remembering the importance of all student higher education experiences, many of which are beyond the scope of the actual classes.
\end{abstract}

\section{KEYWORDS}

Corona, Coronavirus, COVID, Distance Learning, Educational Technology, Learning, Teaching, Technology, Virus

\section{INTRODUCTION}

In the Spring of 2020, schools around the world suspended face-to-face instruction due to the coronavirus pandemic. Teachers around the world had no choice but to convert face-to-face classes to distance learning, often with short notice, a seemingly daunting task for teachers who had designed their courses for in-person instruction (Petzold, 2020). The transition presented challenges for academic staff, many of whom needed higher levels of technology competency and proficiency than they had

DOI: 10.4018/IJDET.20210101.oa3

This article published as an Open Access article distributed under the terms of the Creative Commons Attribution License (http://creativecommons.org/licenses/by/4.0/) which permits unrestricted use, distribution, and production in any medium, provided the author of the original work and original publication source are properly credited. 
previously acquired, as well as for students who suffered from feelings of isolation through not being able to interact with their classmates or attend in-person classes (Gillett-Swan, 2017).

Most of the early publications about the impacts of the pandemic on education either promoted the benefits of practices such as social distancing and event cancelation (Tate, 2020), challenges faced by students (Supiano, 2020, March 19), technology choices and resources (Darby, 2020, April 14), or the bigger-picture landscape of education and consequences of suspending face-to-face instruction (Ruf, 2020, March 17). Indeed, the only articles found in the scholarly press related to teaching and learning, because of the timeline required for empirical research, were editorials or reports on the course of the instructional transition in one school or geographic region, with limited quantitative data.

The actual experiences of teachers while converting their classes to distance instruction, and thereafter managing the classes, received little attention in the first weeks following the transition. The goal of this study, therefore, was to be among the first to document the experiences of teachers at higher education institutions as the result of converting their classes on short notice. The researchers did this by providing a statistical survey and open-ended questions about the extent to which courses were converted due to the pandemic and the perceived level of difficulty. More detailed exploration of the resulting pedagogy and technical problems were beyond the scope of this baseline study.

This study is, therefore, significant because it is one of the first scholarly publications to seek a world-wide sample of respondents exploring the experiences of higher education faculty as they negotiated the complex and stressful transition from face-to-face instruction to distance learning in existing classes. Furthermore, it considers the levels and categories of support provided by the schools and the future curriculum consequences of the pandemic.

The following research questions guided this study:

RQ1: What were the experiences of higher education faculty in converting classes to distance learning?

RQ2: What instructional technology did higher education faculty use in the classes they converted to distance learning?

RQ3: What were the experiences of students, as perceived by higher education faculty, in classes converted to distance learning?

RQ4: To what extent did schools provide support for the transition of classes to distance learning?

RQ5: To what extent do the higher education faculty think the changes will become part of the curriculum in the long term?

RQ6: How difficult was teaching the classes after they were converted to distance learning?

RQ7: What did the higher education faculty members feel they learned from their experiences of converting classes to distance learning?

The researchers grouped these research questions into constructs of two or more questions each, Teacher Experiences, Instructional Technology, Student Experiences, Curriculum Integration, and Difficulty. These constructs, drawn from the research questions, represented the most salient issues related to the conversion of face-to-face classes to distance learning, and then teaching the classes for the remainder of the semester.

\section{LITERATURE REVIEW}

Little empirical research had yet reached the scholarly literature, as of the completion of this study, about the experiences of higher education faculty as they responded to the COVID-19 pandemic. The scholarly medical literature abounds with studies about the SARS-CoV-2 coronavirus but little literature has yet reached publication that addresses the worldwide consequences for education and educational technology. 


\section{Brief History of the Pandemic}

The SARS-CoV-2 coronavirus, and it's resulting COVID-19 disease in humans, surfaced in Wuhan, China, late in 2019. The first deaths were reported in January 2020 and by late January, multiple countries reported confirmed cases, leading to the declaration of a global health emergency by the World Health Organization (WHO). The virus is highly communicable, including by people showing no symptoms, and many countries recommended or required self-quarantine-at-home and social distance of at least two meters (six feet). Many businesses closed as a result of governmental policy or recommendations (Taylor, 2020, April 28) because no vaccine could be ready for months.

Schools around the world closed or suspended face-to-face instruction. In the space of as little as a few days, higher education faculty had to redesign instruction to pivot classes from in-person to online or other distance learning methods (Gardner, 2020, March 20).

Separated from their familiar on-campus environment, students faced uncertainty, extra costs, anxiety, the effects of social isolation, and even sleep disorders (Cao et al., 2020; Ghebreyesus, 2020; Weissman, 2020). Economically disadvantaged and international students often did not all have their own personal computers or home internet access (Mukherjee, 2020, March 29). In some cases, students who relied heavily on campus resources, like food, housing, and healthcare, had no "home" to return to when their campus closed (Weissman, 2020). As a result, schools needed to innovate.

A poll released in April 2020 by the Kaiser Family Foundation in the US (Kirzinger, Kearney, Hammel \& Brodie, 2020) found that $45 \%$ of American adults said the pandemic had affected their mental health and 19\% said it had a "major impact." A separate Kaiser Family Foundation report (Kirzinger, 2020) indicated that 58\% of US young people ages 18-24 reported that worry and stress related to the coronavirus had negatively impacted their mental health.

In higher education, the importance of the social relationships and the social-emotional distress caused by the pandemic closure of schools rapidly gained attention. Carolyn Foote (in Yorio, 2020) said that addressing student stress caused by uncertainty and isolation was central to the question of remote schooling, not just refining the logistics of making instruction work. She said that educators needed to "stay connected with colleagues, be visible to students, [and] help students be visible to each other" (p. 14).

Lieber (2020, May 1) said that parents send their children to college/university for at least three goals, (1) gaining knowledge and forming improved adult brains, (2) obtaining the diploma that signals perseverance and the ability to succeed to prospective employers, and (3) finding friends and mentors who will support them in their lives, which is difficult to achieve when studying from home, Lieber said.

Many students longed for their return to the campus environment. A student of one of the authors said, "I' $m$ someone who benefits from having a face-to-face conversation and learning in a classroom setting. I've never realized how much I have taken for granted the human interaction here on campus and how much I do truly appreciate what goes on."

Educators in discussion boards reported students disengaging, challenging teachers to keep their students motivated (Higheredandcoronavirus, 2020). Learners become engaged when their learning environment fosters relationships, employs productive instructional strategies, and encourages social and emotional development. As a result, engaged learners "exhibit behaviors, thinking processes, or emotions that indicate they are connecting with course materials, with the teacher, and with each other" (Rice \& Kipp, 2020, May 6).

\section{Consequences for Higher Education}

The pandemic need to convert classes to distance learning was eye-opening to many people about the potential of using educational technology to create virtual classrooms, live lectures, online tests and quizzes, the sharing of documents, and doing so in a way that was effective (Mahalakshmi \& Radha, 2020). Many of the tools needed for the conversion of classes to distance learning were already available at the schools, such as existing learning management systems and conferencing software like Zoom 
and MS Teams (Gardner, 2020, March 20). The authors know anecdotally that some teachers and schools developed their own technology solutions, adapting software or apps designed for other uses.

Many scholars have observed that courses that are converted to distance learning on an emergency basis are not true online distance learning (ODL) classes because they are often not well-considered, theory-based instructional designs for sustainable online learning but rather are "ad-hoc, low fidelity mitigation strategies" (Gardner, 2020, March 20, p. 2). Professors who converted their classes to distance learning often did not have the expertise required for online teaching and learning pedagogy, finding it to be an intimidating task (Petzold, 2020). The challenges were complicated by the fact that the majority of higher education teachers have never actually taken a course in teaching (Bailey \& Card, 2009), much less about instructional design for online learning. DeRosa recommended not thinking of "converting" or "translating" a class to distance learning for one semester, but rather thinking in terms of "adapting" which, she said, requires faculty to understand the choices they have and to make those choices from an informed perspective (Supiano, 2020, April 30), or in other words, to make decisions based on the affordances of the educational resources (Marek \& Wu, 2020).

\section{Teacher Experiences}

The few scholarly papers that have been published about teacher experiences in response to the pandemic have been limited. For example, a study of higher education teachers in the Ghaziabad region of India found that the actual benefits of virtual teaching were less than expected as a result of issues of network connectivity, training, and lack of the personal touch limited the adoption and success of virtual classrooms (Arora \& Srinivasan, 2020). Past research has shown that in 2016 compared to 2002, faculty were progressively less enthusiastic about online instruction because the "normalization" of online distance learning made faculty more sensitive to the "transactional gap created by time and location separation" and other negative factors (Perry \& Steck, 2019, p. 10).

The rapidly-change environment of teaching during the coronavirus pandemic, and the fragmented nature of the scholarly research, as of this writing, led the authors to conclude that a baseline study of the experiences of teachers worldwide, reflecting on their transition of classes to distance learning, would be valuable.

\section{METHODS}

\section{Instrument}

The researchers used a Google Forms survey to collect data answering all seven of the research questions, including quantitative questions, most of which were answered by Likert-like scales, and one research question answered by open-ended answers. The following section describes the research design.

Because the coronavirus pandemic, and the suspension of face-to-face instruction, was unprecedented in the modern age, no previous model or research design existed that could be adapted for this study. As a result, the researchers developed a survey instrument based on journalistic reports, professional publications, and online articles focusing on higher education; editorials about the ramifications for higher education; and discussion threads in online faculty discussion forums. The quantitative portion of the instrument included 17 items, 16 with Likertlike scales, and one with checkboxes. In additional, participants answered several demographic questions to allow examination of differences found among the demographic variables, such as age, region of the world, faculty rank, discipline, years of teaching, and incorporation of instructional technology into classes in previous semesters.

The researchers created a construct for each of the quantitative research questions, with two or more individual survey questions per construct. The complete list of questions, sorted by construct, 
is in Table 1 in the Findings section. The six constructs were Teacher Experiences, Instructional Technology, Student Experiences, Curriculum Integration, and Difficulty.

The researchers tested the questionnaire in a pilot study with 61 colleagues, who did not participate in the final data collection, and the overall internal consistency was found to be acceptable (Cronbach's Alpha at 0.79). A native English-speaking expert in survey methodology for scholarly research assessed face-validity and suggested minor wording changes in some questions. The final survey questionnaire received minor adjustments based on both the pilot study results and the validity feedback. The Human Subjects Institutional Review Board at the first author's institution, Wayne State College, Wayne, Nebraska, USA, approved the study, including the final methodology and the statement of informed consent at the beginning of the online survey document.

\section{Procedures}

The researchers extended the invitation to participate to higher education faculty members who had converted courses to distance learning via multiple channels and platforms. These included providing the Google Forms link in ResearchGate discussions, LinkedIn education-oriented groups, Twitter posts tagging selected education-oriented keywords and accounts, a Facebook COVID-19 faculty discussion group, an ICCE Conference Education Group, personal social media posts, and emails to colleagues. The researchers exported the Google Forms results to the SPSS statistical analysis software for descriptive statistics, ANOVA analysis, and Post Hoc tests.

Qualitative analysis of the one open-ended question used an iterative process, described by Creswell (2011). The researchers initially grouped the answers in open categories and then refined them to attain a theoretical focus (Chwo, Marek \& Wu, 2018). They continued an iterative process, comparing the potential themes with the original data and using reflective analysis (Richards \& Lockhart, 1994) in order to finalize the resulting themes.

\section{FINDINGS}

\section{Demographics of Participants}

The researchers asked the 418 respondents 11 demographic questions to allow understanding of the people responding to the survey. The demographic questions consisted of checkboxes for categories, but also allowed participants to add their own categories, often duplicating each other. Before final analysis, the researchers reviewed and groups these additional categories to remove the duplication. After the cutoff for data collection, the researchers determined that some demographic categories lay beyond the scope of the current analysis. The demographics, categories, and percentages are display in Table 1.

By far the most responses were from Asia, making up 90.2\% of the completed surveys, followed by North American and European respondents. Close to a quarter (26.3\%) had never taught via distance learning before. The academic ranks of most participants were either Instructor/Lecturer $(34.9 \%)$ or Assistant Professor/Senior Lecturer (48.3\%). Most were between 31 and 50 years old.

Over 30 disciplines were reported by participants. After grouping by the researchers, $26.6 \%$ of responders were in the humanities and social science, $18.4 \%$ were in business, $12.4 \%$ in computer science, $12 \%$ in hard sciences and mathematics, $10.3 \%$ from technology and engineering fields, $9.3 \%$ education, $7.7 \%$ from medical-related fields, and 3.3\% from Fine Arts, plus a few other isolated disciplines. Years of teaching by the participants was also well-balanced.

Participants reported that $95.5 \%$ of them had converted undergraduate classes to distance learning as the result of the pandemic. One-third of the respondents (32.3\%) converted graduate classes. Twentyeight-point-seven percent had converted both graduate and undergraduate classes. Most participants (64.4\%) said they were using a combination of synchronous and asynchronous forms of instruction, with $21.2 \%$ using asynchronous instruction only and $14.4 \%$ using synchronous instruction only. 
Table 1. Demographic, category, and percentage

\begin{tabular}{|c|c|c|}
\hline Demographic & Category & Percentage $(\%)$ \\
\hline \multirow{8}{*}{ Region } & Asia & 90.2 \\
\hline & Africa & 1.0 \\
\hline & Europe & 3.2 \\
\hline & North America & 4.8 \\
\hline & South America & 0.2 \\
\hline & Central America & 0.2 \\
\hline & Caribbean & 0.2 \\
\hline & Middle East & 0.2 \\
\hline \multirow{3}{*}{$\begin{array}{l}\text { Number of online courses taught } \\
\text { before pandemic }\end{array}$} & Zero & 26.3 \\
\hline & 1 to 4 & 67.7 \\
\hline & 5 or More & 6 \\
\hline \multirow{5}{*}{ Faculty Rank } & Adjunct & 1.9 \\
\hline & Instructor/Lecturer & 34.9 \\
\hline & Assistant Professor/Senior Lecturer & 48.3 \\
\hline & Associate Professor & 9.6 \\
\hline & Full Professor & 5.3 \\
\hline \multirow{8}{*}{ Discipline } & Business & 18.4 \\
\hline & Computer Science & 12.4 \\
\hline & Education & 9.3 \\
\hline & Engineering/ Technology & 10.3 \\
\hline & Fine Arts (Art, Music, Theatre, etc.) & 3.3 \\
\hline & Humanities \& Social Science (History, Language, etc.) & 26.6 \\
\hline & $\begin{array}{l}\text { Medical Science (Physician, Nurse, Medical technology, } \\
\text { Pharmacy, etc.) }\end{array}$ & 7.7 \\
\hline & $\begin{array}{l}\text { Science (Physics, Biology, Chemistry, Geology, } \\
\text { Mathematics, Statistics, and etc.) }\end{array}$ & 12.0 \\
\hline \multirow{3}{*}{ Years of Teaching } & 10 or Less & 40.4 \\
\hline & 11 to 20 & 38.8 \\
\hline & 21 or More & 20.8 \\
\hline \multirow{3}{*}{ Teaching Location } & Home & 97.6 \\
\hline & School & 0.2 \\
\hline & Both & 2.2 \\
\hline \multirow{4}{*}{$\begin{array}{l}\text { Number of Undergraduate Class } \\
\text { this semester }\end{array}$} & Zero & 4.5 \\
\hline & 1 to 3 & 47.0 \\
\hline & 4 to 6 & 38.5 \\
\hline & 7 or Above & 10.0 \\
\hline
\end{tabular}




\begin{tabular}{|l|l|l|}
\hline \multicolumn{1}{|c|}{ Demographic } & \multicolumn{1}{|c|}{ Category } & \multicolumn{1}{|c|}{ Percentage (\%) } \\
\hline \multirow{4}{*}{$\begin{array}{l}\text { Number of Graduate Class this } \\
\text { semester }\end{array}$} & Zero & 67.7 \\
\cline { 2 - 3 } & 1 to 3 & 21.5 \\
\cline { 2 - 3 } & 4 to 6 & 7.2 \\
\cline { 2 - 3 } & 7 or Above & 3.6 \\
\hline \multirow{4}{*}{ Instruction Method } & Synchronous & 14.4 \\
\cline { 2 - 3 } & Asynchronous & 21.2 \\
\cline { 2 - 3 } Technology use in past semesters & Combination of Both & 64.4 \\
\cline { 2 - 3 } & No & 53.1 \\
\cline { 2 - 3 } & Yes & 46.9 \\
\hline
\end{tabular}

The respondents answered a question about their past history incorporating technology into classes, prior to the pandemic semester. Over half (53.1\%) said they had never incorporated technology beyond the basics of PowerPoint slides or discipline-specific hardware/software. The rest cited a dizzying array of platforms previously used, such as Google Meet, Facebook groups, Zoom, Kahoot, Microsoft Teams, and Edpuzzle.

Other than the uneven balance of Asian versus other faculty responding (see discussion), the researchers believed that the survey participants represented a reasonable cross-section of higher education faculty around the world. The following section describes the quantitative findings.

\section{Quantitative Analysis}

The researchers answered the six quantitative research questions by developing constructs for each question, with from two to six individual questions per construct. Table 2 presents the overall structure of the instrument, the research questions and related construct names, and the individual survey questions grouped in each construct, along with the means and standard deviations of each. ANOVA analysis and Post Hoc tests were also conducted to test the significant value of the construct against the demographic categories.

\section{Teacher Experiences}

To answer Research Question 1, about the experiences of higher education faculty in converting classes to distance learning, the construct Teacher Experiences included four questions. Question 1.1 asked about readiness to switch classes to distance teaching. The answers indicated that the respondents were slightly more positive than neutral about their readiness to convert their classes $(M=3.5)$.

The second question, 1.2., asked about whether they based their converted classes on theory or research-based teaching approaches. The mean answer $(M=3.29)$ was between 3 , same as when teaching face-to-face, and 4, more than usual. The third question in the Teacher Experiences construct, 1.3., asked how hard or easy the conversion process was in terms of planning and implementing the changes. The answer $(M=2.75)$ was between 2 , somewhat hard, and 3, average.

Question 1.4. was about how hard has distance learning been after converting the class or classes for the responding teacher. The mean answer $(M=2.80)$ lay between 2 , somewhat hard, and 3, like any class.

The overall construct had a mean of 3.086 and a standard deviation of 0.727. Questions 1.1. and 1.2., about teacher readiness and use of theory, were on the positive side of the balance, whereas question 1.3. and 1.4., about the difficulty of converting and teaching the converted classes, averaged on the negative side. Because each of the questions in the construct treated the value 3 as neutral 
Table 2. Research questions, constructs, and survey questions

\begin{tabular}{|c|c|c|}
\hline Questions & $M$ & $S D$ \\
\hline $\begin{array}{l}\text { RQ1: What were the experiences of teachers in converting classes to distance learning? } \\
\text { (Construct: Teacher Experiences) }\end{array}$ & 3.086 & 0.727 \\
\hline 1.1. As a faculty member, how ready were you to switch your classes to distance teaching? & 3.50 & 0.973 \\
\hline $\begin{array}{l}\text { 1.2. To what extent have you based your converted classes on theory or research-based teaching } \\
\text { approaches? }\end{array}$ & 3.29 & 1.015 \\
\hline $\begin{array}{l}\text { 1.3. How hard or easy was the conversion process in terms of planning and implementing the } \\
\text { changes? }\end{array}$ & 2.75 & 0.945 \\
\hline 1.4. How hard has distance learning been for you, as a teacher, after converting your class(s)? & 2.80 & 1.046 \\
\hline $\begin{array}{l}\text { RQ2: What instructional technology did teachers use in classes that were converted to } \\
\text { distance learning? (Construct: Instructional Technology) }\end{array}$ & 3.29 & 0.982 \\
\hline 2.1. To what extent was the instructional technology you used familiar to you and your students? & 3.29 & 0.982 \\
\hline 2.2. Which technology tools are you using in your converted classes (check all that apply)? & N/A & \\
\hline $\begin{array}{l}\text { RQ3: What were the experiences of students as perceived by teachers, in classes converted to } \\
\text { distance learning? (Construct: Student Experiences) }\end{array}$ & 3.372 & 0.558 \\
\hline $\begin{array}{l}\text { 3.1. As a faculty member, how ready do you think the students were to change their learning } \\
\text { behaviors to distance learning after the COVID-19 restrictions? }\end{array}$ & 3.00 & 1.033 \\
\hline $\begin{array}{l}\text { 3.2. How many of your students owned a computer and had home internet access when distance } \\
\text { learning began? }\end{array}$ & 4.01 & 0.747 \\
\hline $\begin{array}{l}\text { 3.3. To what degree have your students participated or disengaged (stopped participating) in your } \\
\text { converted distance learning class(s)? }\end{array}$ & 3.38 & 0.957 \\
\hline $\begin{array}{l}\text { 3.4. To what extent did you try to ease the concerns of students and encourage them to persist with } \\
\text { their schoolwork? }\end{array}$ & 3.85 & 0.866 \\
\hline 3.5. How hard has distance learning been for your students after converting your class(s)? & 2.61 & 0.951 \\
\hline $\begin{array}{l}\text { RQ4: To what extent did schools provide support for the transition of classes to distance } \\
\text { learning? (Construct: School Support) }\end{array}$ & 3.456 & 0.935 \\
\hline $\begin{array}{l}\text { 4.1. To what degree did your school provide sufficient training and mentoring during the conversion } \\
\text { of your class(s)? }\end{array}$ & 3.48 & 0.999 \\
\hline $\begin{array}{l}\text { 4.2. To what degree did your school provide resources and other assistance as you made the } \\
\text { conversion of your class(s)? }\end{array}$ & 3.44 & 0.995 \\
\hline $\begin{array}{l}\text { RQ5: To what extent do the teachers think the changes will become part of the curriculum in } \\
\text { the long term? (Construct: Curriculum Integration) }\end{array}$ & 3.635 & 0.708 \\
\hline $\begin{array}{l}\text { 5.1. What are the chances that your converted class format(s) will be in the long-term curriculum } \\
\text { after face-to-face classes resume? Unlikely to Very (neg to Pos) }\end{array}$ & 3.46 & 1.006 \\
\hline $\begin{array}{l}\text { 5.2. If you were to continue to teach your classes(s) via distance learning, how much would you } \\
\text { change what you have done this semester to make improvements? }\end{array}$ & 3.81 & 0.843 \\
\hline $\begin{array}{l}\text { RQ6: How difficult was teaching your class after it was converted to distance learning? } \\
\text { (Construct: Difficulty) }\end{array}$ & 3.605 & 0.669 \\
\hline $\begin{array}{l}\text { 6.1. To what extent did you experience stress after transitioning from the conventional classroom to } \\
\text { distance teaching? }\end{array}$ & 3.17 & 0.805 \\
\hline $\begin{array}{l}\text { 6.2. What is your workload for your classes by distance teaching, compared to when you were } \\
\text { teaching face-to-face? }\end{array}$ & 4.04 & 0.840 \\
\hline \multicolumn{3}{|c|}{$\begin{array}{l}\text { RQ7 (Qualitative): What did the faculty members feel they learned from their experiences of converting classes } \\
\text { to distance learning? }\end{array}$} \\
\hline
\end{tabular}


or average, $M=3.086$ indicated that the overall average teacher experience was slightly toward the positive side. The standard deviation, however, indicated a wide variation in the experience of individual faculty responding to the survey. The individual questions had even wider standard deviations, from 0.945 for question 1.3. to 1.046 for question 1.4.

The answer to Research Question 1, therefore, is that the responding faculty had some experiences and influences that were negative or undesirable, balanced by some that were positive or beneficial. Individual faculty reported a wide range of positive and negative perceptions.

\section{INSTRUCTIONAL TECHNOLOGY}

To answer Research Question 2, about the instructional technology the higher education faculty used in the classes they converted to distance learning, the construct Instructional Technology included two questions. Question 2.1. asked to what extent the instructional technology the faculty member ended up using was familiar to the respondent and to the respondent's students. The answers $(M=$ $3.29, S D=0.982$ ) were between 3 , somewhat familiar, and 4, mostly familiar.

Question 2.2. asked the participants to select check-boxes or enter free text to describe the categories of technology they used in their converted classes. The researchers concluded that detailed analysis was beyond the scope of the current study, but $84.5 \%$ indicated that they were using chat applications, such as Messenger, Line, or Whatsapp. "Live" audio or video class meetings were used by $78.3 \%$ of the respondents. A standardized campus learning management system (LMS), such as Canvas or D2L, was used by $43 \%$ of the respondents. LMS systems not provided by their institutions were used by $62.8 \%$. Forth-three percent used email, $14.3 \%$ used personal phone calls, and $13.9 \%$ used social media platforms. Postal mail was used by nine respondents $(2.1 \%)$.

The answer to Research Question 2, therefore, is that the responding faculty used a wide range of technology systems in their converted class. Some, but not all, were provided by their schools. Often the faculty were not full familiar with the teaching and learning technology they ended up using.

\section{Student Experiences}

To answer Research Question 3, about the experiences of students with classes converted to distance learning, as perceived by their faculty, the construct Student Experiences included four questions. Question 3.1. asked the respondents how ready they thought their students were to change their learning behaviors to distance learning after the COVID-19 restrictions. The answers indicated that the faculty perceived that their students were neutral or possibly ambivalent about the changes $(M=$ $3.00)$. The question had one of the highest standard deviations in the study $(S D=1.033)$ indicating considerable variation.

Question 3.2. was about the teacher's understanding of how many students owned a computer and had home internet access when distance learning began. On average, the teachers perceived that all but a few of their students $(M=4.01, S D=0.747)$ had the computer or home internet access they needed.

Question 3.3. asked to what degree students participated or disengaged in the converted distance learning class or classes. The answer $(M=3.38, S D=0.957)$ was between 3 , no change, and 4, participated somewhat more. The high standard deviation indicated a wide range of perceived student behaviors.

Question 3.4. asked whether the teachers tried to ease the concerns of students and encourage them to persist with their schoolwork. The answer $(M=3.85, S D=0.866)$ indicated that as a whole, teachers applied themselves to addressing the concerns of their students, but with a wide variation which could reflect the inclinations of the teacher or the need expressed by the students.

The final question in the construct, 3.5., asked the participant's perception of how hard distance learning had been for their students after the conversion of their classes. The teachers perceived that the converted classes were between 2 , somewhat hard for the students, and 3, like any class $(M=$ 
2.61, $S D=0.951$ ) but the answers spanned the five-point Likert-scale. Over half of the teachers said that the converted classes had been somewhat hard or very hard for their students.

The overall construct Student Experiences leaned somewhat toward the positive side $(M=3.372$, $S D=0.558$ ). The answer to Research Question 3, therefore is that diverse factors, ranging from technology access to motivation, and teacher support, influenced the experience of the students, as perceived by their teachers. Although these factors leaned toward the somewhat positive, students had extensive negative experiences.

\section{School Support}

The construct School Support answered Research Question 4, with two survey questions. Question 4.1. asked to what degree the respondent's school provided sufficient training and mentoring during the class conversion. The response $(M=3.48, S D=0.999)$ indicated a wide range in answers, averaging between 3, enough to get by, and 4, good support. Only $4.1 \%$ of the respondents indicated no support at all.

Question 4.2. was a companion to 4.1., this time asking about the level of resources and other assistance made available by the school. The similar answers $(M=3.44, S D=0.995)$ were between 3 , enough to get by, and 4, good support, with very similar variation among responses.

The overall construct School Support leaned positive $(M=3.456, S D=0.935)$, meaning that the answer to Research Question 4 is that most teachers believed that they had received sufficient training, mentoring, resources, and support from their schools.

\section{Curriculum Integration}

The construct Curriculum Integration answered Research Question 5, about whether the courses converted to distance instruction might remain distance learning in the long-term curriculum, with two survey questions. Question 5.1. asked respondents about the chances that their converted class format(s) would be in the long-term curriculum after face-to-face classes resume. The results $(M=$ $3.46, S D=1.006$ ) fell between 3, unknown, and 4, somewhat likely, with wide variation in the answers.

Question 5.2., about how much change and improvements the teacher would make in their converted classes, if they were to be taught again via distance learning in the future. The mean answer $(M=3.81, S D=0.843)$ was between 3, same amount as for any class, and 4, quite a few changes. Only three respondents $(0.7 \%)$ thought no changes would be needed. Quite a few changes, 4 , received by far the most responses, $(58 \%)$.

The answers to the construct Curriculum Integration $(\mathrm{M}=3.635, \mathrm{SD}=0.708)$ means that the overall answer to Research Question 5 is that the respondents perceived that there was potential for their classes to be taught via distance learning after face-to-face classes resumed, but most saw the need to make substantial changes in their rapidly-crafted pandemic instructional designs.

The construction Difficulty answered the final quantitative research question, 6, with two survey questions. In Question 6.1., about stress experienced by the respondents after transitioning to distance teaching, the answers $(M=3.17, S D=0.805)$ were between 3, a moderate amount of stress but manageable, and 4, enough to cause some issues. Question 6.2, about the teacher's workload after converting the classes compared to regular face-to-face teaching, had the highest mean of any question on the test $(\mathrm{M}=4.04, \mathrm{SD}=0.840)$. Answers 4 , somewhat more work, and 5, very much more work, together were selected by $77.5 \%$ of the respondents.

The answers to the construct of Difficulty $(M=3.605, S D=0.669)$ mean that the overall answer to Research Question 6 is that the respondents experienced moderate to high stress and most experienced moderate to considerably increased workloads in completing their courses after the hastily conversion to distance learning. 


\section{ANOVA AND POST HOC ANALYSIS}

The researchers ran a series of ANOVA and Post Hoc tests comparing the constructs to various demographic items. Many were not significant, indicating no differences among the subdivisions of the demographic category. Those that are significant are reported below in Table 3.

Table 3. Summary of descriptive statistics and ANOVA test for teacher experiences, instructional technology, and difficulty based on different demographic categories

\begin{tabular}{|c|c|c|c|c|c|c|}
\hline \multirow{2}{*}{$\begin{array}{c}\text { Construct } * * \\
\text { Demographic Category }\end{array}$} & \multirow{2}{*}{ Category } & \multirow{2}{*}{$\mathbf{N}$} & \multirow{2}{*}{ Mean } & \multirow{2}{*}{$\begin{array}{l}\text { SD. } \\
\text { Deviation }\end{array}$} & \multicolumn{2}{|c|}{ ANOVA Test } \\
\hline & & & & & $\boldsymbol{F}$ & $p$ \\
\hline \multirow{3}{*}{$\begin{array}{l}\text { Teacher Experiences ** } \\
\text { Number of Online Courses }\end{array}$} & Zero & 110 & 2.9841 & .80799 & \multirow{3}{*}{3.073} & \multirow{3}{*}{$.047 *$} \\
\hline & 1 to 4 & 283 & 3.0998 & .68931 & & \\
\hline & 5 or more & 25 & 3.3700 & .70015 & & \\
\hline \multirow{4}{*}{$\begin{array}{l}\text { Instructional Technology } \\
* * \\
\text { Number of Online Courses }\end{array}$} & Zero & 110 & 3.3273 & 1.13420 & \multirow{4}{*}{3.470} & \multirow{4}{*}{$.032 *$} \\
\hline & 1 to 4 & 283 & 3.5336 & .89211 & & \\
\hline & 5 or more & 25 & 3.8400 & .98658 & & \\
\hline & Combination of both & 269 & 3.3703 & .52434 & & \\
\hline \multirow{3}{*}{$\begin{array}{l}\text { Difficulty** } \\
\text { Number of Online Courses }\end{array}$} & Zero & 110 & 3.7409 & .67976 & \multirow{3}{*}{3.229} & \multirow{3}{*}{$.041 *$} \\
\hline & 1 to 4 & 283 & 3.5512 & .66580 & & \\
\hline & 5 or more & 25 & 3.6200 & .58238 & & \\
\hline \multirow{5}{*}{$\begin{array}{l}\text { Difficulty } * * \\
\text { Faculty Rank }\end{array}$} & Adjunct & 8 & 2.8750 & .95431 & \multirow{5}{*}{3.270} & \multirow{5}{*}{$.012 *$} \\
\hline & Instructor/Lecturer & 146 & 3.6575 & .62077 & & \\
\hline & $\begin{array}{l}\text { Assistant Professor/Senior } \\
\text { Lecturer }\end{array}$ & 202 & 3.6312 & .65325 & & \\
\hline & Associate Professor & 40 & 3.5250 & .74205 & & \\
\hline & Full Professor & 22 & 3.4318 & .72859 & & \\
\hline
\end{tabular}

${ }^{*} p<.05$

Table 3 shows that the mean difference in teacher experiences among the categories of numbers of courses taught online prior to the COVID-19 semester was statistically significant $(p=0.047)$. Since there was a significant main effect for the number of online courses, a follow-up procedure using Fisher's LSD post-hoc test determined which number of online courses was different from the others (Table 4). The main effect of teacher experiences on number of online courses showed a significant difference between teaching zero courses and teaching 5 or more courses online prior to the COVID-19 semester. However, there was no significant difference between teaching zero courses and teaching one to four courses. The researchers concluded that there was no significant difference because faculty who have only taught a limited number of previous classes online are little more experienced than those who have taught none.

Table 3 also shows that the mean difference in instructional technology among the categories of numbers of courses taught online prior to the COVID-19 semester was statistically significant $(p=$ 0.032). Since Table 3 had shown that there was a significant main effect for number of online courses, Fisher's LSD post-hoc test determined which category of online courses taught was different from the others (Table 5). For the main effect of instructional technology on number of online courses, there was a significant difference between zero courses and 5 or more different courses online prior 
Table 4. Summary of Fisher's LSD Post-Hoc test for mean differences between number of online courses in teacher experiences

\begin{tabular}{|c|c|c|c|c|c|c|}
\hline \multirow{2}{*}{$\begin{array}{c}\text { Number of } \\
\text { Online Courses }\end{array}$} & \multirow{2}{*}{$\begin{array}{c}\text { Number of } \\
\text { Online Courses }\end{array}$} & \multirow[b]{2}{*}{ Mean Difference (I-J) } & \multirow{2}{*}{$\begin{array}{l}\text { SD. } \\
\text { Error }\end{array}$} & \multirow[b]{2}{*}{ Sig. } & \multicolumn{2}{|c|}{ 95\% Confidence Interval } \\
\hline & & & & & $\begin{array}{l}\text { Lower } \\
\text { Bound }\end{array}$ & $\begin{array}{l}\text { Upper } \\
\text { Bound }\end{array}$ \\
\hline \multirow{2}{*}{ Zero } & 1 to 4 & -.11573 & .08123 & .155 & -.2754 & .0439 \\
\hline & 5 or more & $-.38591^{*}$ & .16019 & .016 & -.7008 & -.0710 \\
\hline \multirow{2}{*}{1 to 4} & Zero & .11573 & .08123 & .155 & -.0439 & .2754 \\
\hline & 5 or more & -.27018 & .15085 & .074 & -.5667 & .0263 \\
\hline \multirow{2}{*}{5 or more } & Zero & $.38591 *$ & .16019 & .016 & .0710 & .7008 \\
\hline & 1 to 4 & .27018 & .15085 & .074 & -.0263 & .5667 \\
\hline
\end{tabular}

* The mean difference is significant at the 0.05 level.

Table 5. Summary of Fisher's LSD Post-Hoc test for mean differences between number of online courses in instructional technology

\begin{tabular}{|c|c|c|c|c|c|c|}
\hline \multirow{2}{*}{$\begin{array}{c}\text { Number } \\
\text { of Online } \\
\text { Courses }\end{array}$} & \multirow{2}{*}{$\begin{array}{c}\text { Number of } \\
\text { Online Courses }\end{array}$} & \multirow[b]{2}{*}{ Mean Difference (I-J) } & \multirow{2}{*}{$\begin{array}{l}\text { SD. } \\
\text { Error }\end{array}$} & \multirow[b]{2}{*}{ Sig. } & \multicolumn{2}{|c|}{ 95\% Confidence Interva } \\
\hline & & & & & $\begin{array}{l}\text { Lower } \\
\text { Bound }\end{array}$ & $\begin{array}{l}\text { Upper } \\
\text { Bound }\end{array}$ \\
\hline \multirow{2}{*}{ Zero } & 1 to 4 & -.20630 & .10864 & .058 & -.4199 & .0073 \\
\hline & 5 or more & $-.51273 *$ & .21424 & .017 & -.9339 & -.0916 \\
\hline \multirow{2}{*}{1 to 4} & Zero & .20630 & .10864 & .058 & -.0073 & .4199 \\
\hline & 5 or more & -.30643 & .20175 & .130 & -.7030 & .0901 \\
\hline \multirow{2}{*}{5 or more } & Zero & $.51273^{*}$ & .21424 & .017 & .0916 & .9339 \\
\hline & 1 to 4 & .30643 & .20175 & .130 & -.0901 & .7030 \\
\hline
\end{tabular}

* The mean difference is significant at the 0.05 level.

to the COVID-19 semester. However, there was no significant difference between zero courses and one to four courses. The researchers concluded that this difference is understandable because faculty with extensive experience are considerably less likely to experience difficulties than people who are only beginners.

Table 3 also shows that the mean difference in difficulty among the categories of numbers of courses taught online prior to the COVID-19 semester was statistically significant $(p=0.041)$. A follow-up procedure using Fisher's LSD post-hoc test determined which categories of online courses were different from the others (Table 6). The main effect of difficulty on number of online courses, showed a significant difference between zero courses and 1 to 4 courses. However, there was no significant difference between zero courses and 5 or more courses, or between 1 to 4 and 5 or more courses. The researchers concluded that the difference between having taught no classes previously and having taught one to four is to be expected because respondents having taught no distance learning classes previously were more likely to encounter difficulty.

Table 3 also shows that the mean difference in difficulty among categories of faculty rank was statistically significant $(p=0.012)$. A follow-up procedure using Fisher's LSD post-hoc test determined which category of faculty rank were different from the others (Table 7). The main effect of difficulty on faculty rank showed a significant difference between adjunct and instructor/lecturer, between adjunct and assistant professor/senior lecturer, between adjunct and associate professor, 
Table 6. Summary of Fisher's LSD Post-Hoc test for mean differences between number of online courses in difficulty

\begin{tabular}{|l|l|l|l|l|l|l|}
\hline \multirow{2}{*}{$\begin{array}{c}\text { Number } \\
\text { of Online } \\
\text { Courses }\end{array}$} & \multicolumn{1}{|c|}{$\begin{array}{c}\text { Number of } \\
\text { Online Courses }\end{array}$} & \multicolumn{1}{|c|}{ Mean Difference } & $\begin{array}{c}\text { SD. } \\
\text { Error }\end{array}$ & \multicolumn{2}{|c|}{ Sig. } & \multicolumn{2}{|c|}{$\begin{array}{c}\text { L5\% Confidence Interval } \\
\text { Bound }\end{array}$} & $\begin{array}{c}\text { Upper } \\
\text { Bound }\end{array}$ \\
\hline \multirow{2}{*}{ Zero } & 1 to 4 & $.18967^{*}$ & .07472 & .011 & .0428 & .3365 \\
\cline { 2 - 7 } & 5 or more & .12091 & .14734 & .412 & -.1687 & .4105 \\
\hline \multirow{2}{*}{1 to 4} & Zero & $-.18967^{*}$ & .07472 & .011 & -.3365 & -.0428 \\
\cline { 2 - 8 } & 5 or more & -.06876 & .13875 & .620 & -.3415 & .2040 \\
\hline \multirow{2}{*}{5 or more } & Zero & -.12091 & .14734 & .412 & -.4105 & .1687 \\
\cline { 2 - 8 } & 1 to 4 & .06876 & .13875 & .620 & -.2040 & .3415 \\
\hline
\end{tabular}

* The mean difference is significant at the 0.05 level.

Table 7. Summary of Fisher's LSD Post-Hoc test for mean differences between faculty rank in difficulty

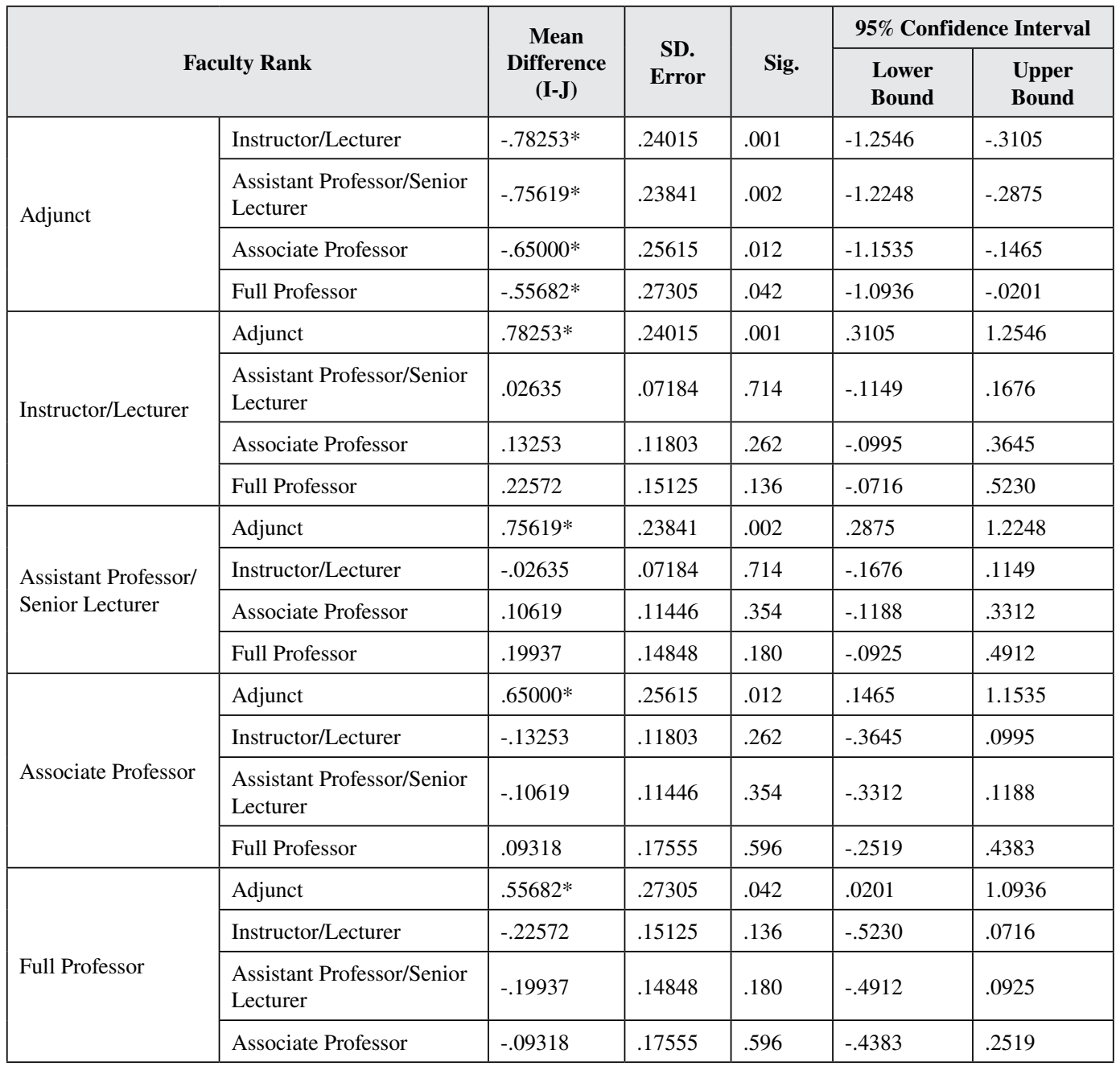

* The mean difference is significant at the 0.05 level. 
and between adjunct and full professor. However, there was no significant difference of faculty rank between instructor/lecturer and assistant professor/senior lecturer, between instructor/lecturer and associate professor, or between instructor or lecturer and full professor. The researchers concluded that these differences existed because, in most cases, adjunct faculty is often the least experienced, and thus adjunct respondents were more likely to experiences difficulties in converting their classes.

\section{QUALITATIVE ANALYSIS}

Research Question 7 was answered by performing theme analysis on the answers to the open-ended qualitative question "What lessons have you learned from this process of teaching classes converted on short notice due to the coronavirus?" Four primary themes emerged, (1) teaching styles and teacher challenges, (2) student learning styles and challenges, (3) technology, and (4) planning and adaptability.

\section{Teaching Styles and Teacher Challenges}

The faculty responding to the open-ended question discussed their instructional strategies for their converted classes. "I needed to revise all my lecture notes to make them more detailed with lots of pictures/diagrams/videos, since I cannot explain thoroughly to the students as I did in the classes," said one. As the quantitative data showed, respondents with more experience teaching online felt more prepared. "Because I have done it before and all materials are already in soft-copy, or onlineready, I find it less stressful," said one.

Some comments were about how they interacted with students, stressing the need for proactive communication. "Dealing with students with empathy, keeping them informed, and having them on social media helped the transition and the motivation to continue," said one respondent, "though we have around $10 \%$ of the students withdrawing."

The teachers also reported lessons they learned about their own readiness. "I should have learned the new IT sooner, by the time it was needed (like Covid-19, who has ever expected it to happen?)," said one respondent. "Then I wouldn't be panicking and could continue to perform my job with the least hiccups."

Many of the respondents felt good about their efforts. "I have learnt that when put to the test, I'm able to perform in a very stressful situation," said a faculty member. "I have never been comfortable with technology but somehow I have overcome the many issues I faced. I also realize that I need to overcome my discomfort with technology and work on improving my skills."

\section{Student Learning Styles and Challenges}

The respondents to the survey had many comments about the reactions of their students to the abrupt transition to distance learning. Some found that students adapted well, but others saw dysfunctional behaviors. "Students do not understand as much as they put on that they do," said one teacher. "They depend on peer teaching around synchronous classes more than we realize, and when separated, it makes that more difficult."

Other comments addressed the readiness of students to adapt to online learning. "Most students are not independent learners and struggle to navigate remote learning, reading without interaction, and time management," said one respondent. "Students are not as tech savvy as is popularly believed," said another respondent. "They definitely are not disciplined enough for remote learning." One faculty member expressed the duality that, "Although students are in tune with technology, they cannot transition that knowledge to the online learning environment!" Another teacher summed up ideas about how students related to the pandemic-driven conversion of classes saying, "Good and motivated students do well and adjust, whereas less motivated students work less or even disappear." 


\section{Technology}

Respondents reported lessons learned technology infrastructure and about training. "Good Internet connectivity is a fundamental requirement in order to ensure successful online distance learning," said one. "Our institution should have a better Wi-Fi connection and also, a ready Plan-B for a better execution during any emergencies," said another. A third added, "We should have practiced the latest technology a long time ago so that we would be well prepared during a pandemic time like this."

Some respondents felt that their institutions were ready for the distance learning challenge, but others did not. "[My country] wasn't ready for distance learning due to limited facilities," lamented one. "Improvement is needed if we want to proceed with distance learning in the future."

\section{Planning and Adaptability}

Many respondents expressed lessons about planning and adaptability. "Distance teaching/learning requires extensive planning," reflected one. "And since we had hardly any planning time for what happened with the onset of the pandemic, this contributed to my feelings of loss of control, etc. I don't feel I did that good a job, and that's ok. If we go online or fully online for fall, I hope they give us enough notice so I can improve my online offerings."

"The lessons I learned from this," said another, "are 1) educators need to be open to the changes in the teaching and learning and willing to step out of their comfort zones, 2) educators need to be equipped with necessary knowledge and skills in online teaching and 3) educators need to keep themselves updated with available online learning platforms/technology."

Other respondents were philosophical. "Change is imminent for the sake of our students. You got to do what you have to do," said one. "We must be open to all possibilities, to keep an open mind in exploring and exhausting resources as well as be empathic to students who are also somewhat shocked by the sudden changes," said another.

These findings, charting the initial consequences of the 2020 unprecedented worldwide conversion of face-to-face classes to Distance Learning, on very short notice, provide insight into the experiences of teachers and their students during the transition, the readiness of academic institutions to support online learning, and the lessons learned by the teachers, themselves. The authors believe that capturing these data early, while the spring semester was still in progress in most areas, provided a baseline that may be different from the memories of the events months or years down the road.

\section{Discussion}

The most important findings of this study were that (1) close to $90 \%$ of the respondents were from The Asia/Pacific Rim region (sample variability), (2) almost every quantitative question had a high variability in answers, (3) respondents experienced considerably higher workloads and stress, (4) although many schools had sanctioned technology solutions, the lion's share of respondents went beyond these systems, using diverse technology, (5) the most common predictor of positive faculty experiences in the conversion to distance learning was experience in previous semesters teaching online, and (6) the respondents emphasized the need to do what it takes to serve their students. The following sections address these findings in detail.

\section{Sample Validity}

According to ourworldindata.org, there are over 12.5 million tertiary education teachers around the world (Ourworldindata, 2020). A truly random sample was beyond the scope of feasibility for this study, leading to the approach of seeking respondents via various world-wide online platforms. The large number of Asian responses may be the result of multiple factors. Western higher education institutions were close to the end of their semesters during data collection, whereas Asian institutions were much earlier in their semesters. Asian faculty may have found it easier to allocate time to complete the survey, since they were not burdened by end-of-the-semester pressures. Asian faculty 
may have also felt more motivation to share their experiences for cultural or practical reasons. Asia also has more recent experience with serious pandemics that the rest of the world, including SARS in 2003, which may make Asian countries more cautious about the spread of pandemics, and which may have sensitized faculty in Asia to the importance of understanding the educational consequences of COVID-19.

In addition, the researchers tracked responses as they came in. The last $10 \%$ of responses, which were mainly American or European, changed the percentages very little, suggesting that data saturation had been achieved. The demographic distributions led the researchers to believe that the sample was appropriately representative. Nevertheless, in interpreting the results of this study, the geographic weighting of the respondents may have affected the validity of the sample in terms of worldwide trends.

\section{Sample Variability}

While only three of the questions in this survey had means below three (representing the middle, neutral, or average answer) most had high variability. The standard deviations of all but three questions were above 0.9 and four questions had standard deviations above 1.0. This indicates that the responses were not concentrated, but rather that the respondents had diverse experiences, both positive and negative, which bely the mostly-positive mean values of most of the scales. The researchers believe that this variability is the result of the considerable differences in how prepared each university was for the transition to all-online, as well as the wide range in the relevant experience levels of individual faculty. Both factors likely made an important contribution to the experiences of individual teachers during the transition. In this case, therefore, the high variation is not a concern about the data, but rather indicative of a meaningful lack of homogeneity in the responses, and therefore signals the considerably different levels of readiness to transition to distance learning of schools and faculty around the world, and the resulting widely varying contexts for distance learning.

\section{Workload and Stress}

The higher education faculty in this study experienced considerably higher workload and stress on average as the result of having to convert their classes to distance learning and complete the semester in that mode. This fits a pattern that is well established in higher education.

Windes \& Lesht (2014) determined that there are different motivating factors and perceptions of teaching online across institutional types. Shih et al. (2003) also stated that successful distance learning needs three elements - policy, people, and technology. Wingo, Ivankova, and Moss (2017) found that faculty were concerned about their workload in online teaching, as well as perceptions of barriers to student success in online learning and manageable class sizes.

While the data showed that the respondents were ready to transform their classes, they should not be interpreted as being enthusiastic about it. Rather, the results of question 1.1 more likely represent an understanding that it was necessary to the safety of themselves and their students, regardless of how troublesome the process might be.

\section{Beyond School-Provided Technology}

It is surprising that only $43 \%$ of respondents used a school-provided learning management system (LMS). This may reflect the respondent's desire to use a different technology format, but it may also reflect the accessibility of those applications provided by the campus. Almost two-thirds of the respondents, on the other hand, used an LMS system NOT provided by their school. In addition, almost $85 \%$ indicated that they were using consumer chat applications, such as Messenger, Line, or Whatsapp, as they worked to engage with their students and ease their concerns. Use of chat applications helps to increase interaction and social presence, and lessen the psychological distance between the teachers and students (Klein et al., 2018). Some schools appear to have tighter policies about using outside systems as an alternative to school-provided systems, but the faculty feeling this need is a reminder that in their everyday personal lives, students and most faculty may use multiple 
communication platforms and to interact with their friends and colleagues. Wu \& Marek (2016) recommended that such platforms be thought of as communication tools, as opposed to teaching tools, and proposed that online instruction should not only permit, but pragmatically acknowledge that multiple overlapping communication platforms are a fact of life, not just for students but also for their teachers. Similarly, students have been shown to prefer to not use their smartphones as learning tools (Chwo et al., 2018; Papadakis, 2018).

\section{Previous Experience}

There were few correlations between the survey questions and the demographics of the respondents except, notably, that past experience teaching online, before the pandemic, predicted the ease and comfort with which the respondents converted and taught their classes after the suspension of faceto-face classes. This finding fits the patterns of pre-pandemic research.

Shea (2007) found that less experienced faculty were more demotivated by the unfamiliar requirements of online pedagogy than more experienced faculty. Nagia et al. (2005) found that faculty who had taught online perceived their level of expertise to range from advanced beginner to competent. Faculty who had never taught online saw themselves as at the novice or advanced beginner stages. Thus, it is not surprising that faculty who had previous experience teaching via distance learning were more comfortable with their rapid transition of face-to-face classes to distance learning.

\section{DOING WHAT IT TAKES}

In their qualitative answers, many of the respondents reported that they had learned the lesson of the need for adaptability and good planning. The frequent repetition of the Planning and Adaptability theme made clear that the respondents were thinking not only about the personal difficulties they faced in converting their classes, but also in terms of serving their students and giving them the best experience possible, under the circumstances.

The finding matches other work in the scholarly literature about passionate and dedicated teachers (Mart, 2013). It is widely acknowledged that teachers teach because of their dedication and feel that student success is their mission as a teacher (Palmer, 1998).

\section{RECOMMENDATIONS}

Based on the findings of this study, the researchers offer the following recommendations:

- Higher education institutions should provide theory-based training and mentoring to faculty concerning online and distance learning pedagogy and instructional design, not just about the use of hardware and software for distance learning. Some $23 \%$ of respondents said that they did not base their converted classes on theory or research-based approaches. Converting a face-toface course to online often requires considerable modification of lesson plans, schedules, and learning activities;

- This training should be performed not just in the face of a crisis, but rather as a longer-term professional development expectation for the faculty. The teachers in this study used instructional technology that was familiar to them, but over half did not use a campus-provided LMS. Although in some cases, there may have been no such system, it implies the need for more ongoing training in the use of educational technology as a standard part of professional development, as opposed to waiting for a crisis to occur;

- Higher Education Institutions should not lose sight of the wealth of experiences that students acquire from higher education which are beyond the scope of the actual classes. Although the faculty in this study described their students as largely neutral or ready to change their learning 
behaviors in light of the pandemic, many students disengaged from the online classes because they missed having a face-to-face conversation and learning in a classroom setting, and longed for the campus social environment. Living independently from parents, social relationships, time management, and other factors are essential part of the higher education learning experience. Particularly for undergraduate students, these personal growth and development experiences cannot easily be replicated in distance/online delivery of classes.

\section{CONCLUSION}

This study has explored the experiences of higher education faculty around the world in 2020 as they converted their classes to distance learning on short notice, and as they taught in that mode for the rest of the semester.

Limitations of the study include the relatively short duration of data collection and the resulting geographic weighting of Asia/Pacific Rim respondents. The researchers were also unable to directly ask students about their experiences, so relied on their teachers' perceptions. Further research could collect data over a longer period of time, seek additional ways to balance the data geographically, and attempt to sample students directly. Although the researchers presented evidence above that suggested that data saturation had been achieved, readers should be cautious about over-generalizing the results, other than as a starting point for future research.

The researchers hope that this first baseline look at the experiences of higher education teachers after the rapid conversion of classes to distance learning will help academia to better understand the dynamics of that transition and the longer-term consequences. 


\section{REFERENCES}

Arora, A. K., \& Srinivansen, R. (2020). Impact of pandemic COVID-19 on the teaching-learning process: A study of higher education teachers. Parabandhan: Indian Journal of Management, 13(4), 43-56. doi:10.17010/ pijom/2020/v13i4/151825

Bailey, C. J., \& Card, K. A. (2009). Effective pedagogical practices for online teaching: Perception of experienced instructors. Internet and Higher Education, 12(3-4), 152-155. doi:10.1016/j.iheduc.2009.08.002

Cao, W., Fang, Z., Hou, G., Han, M., Xu, X., Dong, J., \& Zheng, J. (2020). The psychological impact of the COVID-19 epidemic on college students in China. Psychiatry Research, 287. <ALIGNMENT.qj ></ ALIGNMENT>10.1016/j.psychres.2020.112934

Chwo, S. M. G., Marek, M. W., \& Wu, W.-C. V. (2018). Meta-analysis of MALL research and design. System, 74, 62-72. doi:10.1016/j.system.2018.02.009

Creswell, J. W. (2011). Qualitative Inquiry \& Research Design (3rd ed.). Sage.

Darby, F. (2020, April 14). 5 Low-tech, time-saving ways to teach online during Covid-19. The Chronicle of Higher Education. https://www.chronicle.com/article/5-Low-Tech-Time- Saving-Ways/248519

Gardner, L. (2020, March 20). Covid-19 has forced Higher Ed to pivot to online learning. Here are 7 takeaways so far. The Chronicle of Higher Education. https://www.chronicle.com/article/Covid-19-Has-Forced-Higher$\mathrm{Ed} / 248297$

Ghebreyesus, A. (2020). Psychiatrists Beware! The impact of COVID-19 and pandemics on mental health. Psychiatric Times, 37(3). https://www.psychiatrictimes.com/psychiatrists-beware-impact-coronavirus-pandemicsmental-health

Gillett-Swan, J. (2017). The Challenges of Online Learning: Supporting and Engaging the Isolated Learner. Journal of Learning Design, 10(1), 20-30. doi:10.5204/jld.v9i3.293

Higheredandcoronavirus. (2020). Higher ed and the coronavirus (Facebook group). https://www.facebook.com/ groups/higheredandcoronavirus

Kirzinger, A. (2020). Partying spring breakers don't represent most of America's young adults. Kaiser Family Foundation. https:/www.kff.org/coronavirus-policy-watch/partying- spring-breakers-dont-represent-most-ofamericas-young-adults/

Kirzinger, A., Kearney, A., Hamel, L., \& Brodie, M. (2020). KFF health tracking poll - Early April 2020: The Impact of coronavirus on life in America. Kaiser Family Foundation. https://www.kff.org/health-reform/report/ kff-health-tracking-poll-early-april-2020

Klein, A. Z., Da Silva Freitas, J. C. Junior, Da Silva, J. V. V. M. M., Barbosa, J. L. V., \& Baldasso, L. (2018). The educational affordances of Mobile Instant Messaging (MIM): Results of Whatsapp ${ }^{\circledR}$ used in higher education. International Journal of Distance Education Technologies, 16(2), 51-64. doi:10.4018/IJDET.2018040104

Lieber, R. (2020, May 1). Colleges won't refund tuition. Autumn may force a reckoning. The New York Times. https://www.nytimes.com/2020/05/01/your-money/college-tuition- refunds-coronavirus.html

Mahalakshmi, K., \& Radha, R. (2020). COVID 19: A massive exposure towards web based learning. Journal of Xidian University, 14(4), 2405-2411. doi:10.37896/jxu14.4/266

Marek, M. W., \& Wu, P.-H. N. (2020). Digital Learning Curriculum Design: Outcomes and Affordances. In L. Daniela (Ed.), Pedagogies of Digital Learning in Higher Education. Taylor \& Francis (Routledge). https:// www.routledge.com/Pedagogies-of- Digital-Learning-in-Higher-Education/Daniela/p/book/9780367894832

Mart, C. T. (2013). Passionate teacher: Teacher commitment and dedication to student learning. International Journal of Academic Research in Progressive Education and Development, 2(1), 437-442.

Mukherjee, M. (2020, March 29). What coronavirus outbreak means for global Higher Education. Outlook. https://www.outlookindia.com/website/story/opinion-coronavirus- outbreak-what-does-it-mean-for-globalhigher-education-in-the-time-of-covid-19/349666 
Ourworldindata. (2020). Number of teachers across education levels. https://ourworldindata.org/teachers-andprofessors

Papadakis, S., Kalogiannakis, M., Sifaki, E., \& Vidakis, N. (2018) Access Moodle Using Smart Mobile Phones. A Case Study in a Greek University. In Interactivity, Game Creation, Design, Learning, and Innovation. ArtsIT 2017, DLI 2017. Lecture Notes of the Institute for Computer Sciences, Social Informatics and Telecommunications Engineering, (vol. 229). Springer. doi:10.1007/978-3-319-76908-0_36

Parker, P. (1998). The Courage to Teach. Jossey-Bass.

Perry, D., \& Steck, A. (2019). Changes in faculty perceptions about online instruction: Comparison of faculty groups from 2002 and 2016. Journal of Educators Online, 16(2). Advance online publication. doi:10.9743/ JEO.2019.16.2.8

Petzold, A. M. (2020). Letter to the editor: Resources and recommendations for a quick transition to online instruction in physiology. Advances in Physiology Education, 44, 217-219. doi:10.1152/advan.00049.2020

Rice, K., \& Kipp, K. (2020, May 6). How can educators tap into research to increase engagement during remote learning? https:/www.edsurge.com/news/2020-05-06-how-can-educators-tap-into-research-to-increaseengagement-during-remote-learning

Richards, J. C., \& Lockhart, C. (1994). Reflective Teaching in Second Language Classrooms. Cambridge University Press. doi:10.1017/CBO9780511667169

Ruf, J. (2020) Report: Pandemic may put financial, enrollment strain on colleges. Diverse: Issues in Higher Education. https://diverseeducation.com/article/169894/

Shea, P. (2007). Bridges and barriers to teaching online college courses: A study of experienced faculty in thirtysix colleges. Online Learning Consortium, 11(2), 73-128.

Shih, T. K., Antoni, G. D., Arndt, T., Asirvatham, A., Chang, C., Chee, Y. S., Dow, C., Hung, J. C., Jin, Q., Jung, I., Leong, H. V., Li, S., Lin, F., Liu, J., Sala, N., \& Wang, Y. (2003). A survey of distance education challenges and technologies. International Journal of Distance Education Technologies, 1(1), 1-20. doi:10.4018/jdet.2003010101

Supiano, B. (2020, March 19). How to help students keep learning through a disruption. The Chronicle of Higher Education. https://www.chronicle.com/article/How-to-Help- Students-Keep/248269

Supiano, B. (2020, April 30). Why you shouldn't try to replicate your classroom teaching online. The Chronicle of Higher Education. https://www.chronicle.com/article/Why-You- Shouldn-t-Try-to/248664

Tate, W. F. (2020). COVID-19: Be a part of flattening the curve. Diverse: Issues in Higher Education. https:// diverseeducation.com/article/169901/

Taylor, D. B. (2020). How the coronavirus pandemic unfolded: A Timeline. New York Times. https://www. nytimes.com/article/coronavirus-timeline.html

Weissman, S. (2020). It's a different world. Diverse Issues in Higher Education, 37(4), 10-12.

Windes, D. L., \& Lesht, F. L. (2014). The Effects of Online Teaching Experience and Institution Type on Faculty Perceptions of Teaching Online. Online Journal of Distance Learning Administration, 17(1). https:// www.learntechlib.org/p/155627/

Wingo, N. P., Ivankova, N. V., \& Moss, J. A. (2017) Faculty perceptions about teaching online: exploring the literature using the technology acceptance model as an organizing framework. Online Learning, 21(1), 15-35. doi: 10.10.24059/olj.v21i1.761

Wu, P.-H. N., \& Marek, M. W. (2016). Incorporating LINE Smartphone app affordances: Cross- cultural collaboration, willingness to communicate, and language learning. International Journal of Computer-Assisted Language Learning and Teaching, 6(2), 56-73. doi:10.4018/IJCALLT.2016040104

Yorio, K. (2020, April). Emotional support needed School Library Journal. http://www.slj. com/?detailStory=librarian-spotlights-social-emotional-needs-among-remote-learning-resources 
Michael W. Marek, Ed.D., is a tenured professor of Electronic Media at Wayne State College, Wayne, Nebraska, USA. He teaches communication and multi-platform media courses, including marketing communication, media law, and film criticism. His background includes journalism, broadcasting, tourism, and innovative uses of the internet for interactive communication. He has numerous publications in international journals, as well as a growing list of scholarly book chapters.

Chew Chiou Sheng (PhD) received his Ph.D. in Computer Science (Cognitive Science) from the University of Malaya, Malaysia. He is a senior lecturer-cum-researcher in the Faculty of Computer and Mathematical Sciences at Universiti Teknologi MARA, Melaka, Malaysia. His research interests are Computer Science in Education, Computer-Assisted Learning, Educational Technology, and Cognitive Science.

Wen-Chi Vivian Wu is a distinguished professor of the Department of Foreign Languages at Asia University and a consult of Department of Medical Research in China Medical University in Taiwan. She has published extensively on CALL and technology-related prestigious journals, including CALL, System, Computer in Human Behaviors, and ETS, etc. Her recent research areas include VR, MALL, CALL, cross-cultural communication, and robotics learning. She is a founding member of English Scholars Beyond Borders Association (ESBBS) while also plays an important role for several prestigious international journals for many years, including the editorial board members of the CALL Journal(SSCI), senior advisor of Asian EFL Journal (Scopus), and associate editor of Asian ESP Journal (Scopus). Over the past many years, she has integrated international experiences into her languages courses linking her students with college students and university professors in America and Japan. 